\title{
Spatial Expansion of Human Settlement during the Longshan Period ( 4.5- 3.9 ka BP) and Its Hydroclimatic Contexts in the Lower Yellow River Floodplain, Eastern China
}

\author{
Kaifeng Li ${ }^{1,2}$, Wenhua Gao ${ }^{1, *}, \mathrm{Li} \mathrm{Wu}{ }^{3}$, Hainan Hu ${ }^{1}$, Panpan Gong ${ }^{1}$, Suyuan $\mathrm{Li}^{4}$, Rui Jin ${ }^{4}$ and $\mathrm{Yi} \mathrm{Si}^{4}$ \\ 1 Key Laboratory of Geospatial Technology for the Middle and Lower Yellow River Regions \\ (Ministry of Education), College of Environment and Planning, Henan University, Kaifeng 475004, China; \\ kfli@henu.edu.cn (K.L.); $104753200189 @$ henu.edu.cn (H.H.); 104753200200@henu.edu.cn (P.G.) \\ 2 Cultural Heritage Laboratory of the Yellow River, Henan University, Kaifeng 475001, China \\ 3 Provincial Key Laboratory of Earth Surface Processes and Regional Response in the Yangtze-Huaihe \\ River Basin, School of Geography and Tourism, Anhui Normal University, Wuhu 241002, China; \\ 705233@ahnu.edu.cn \\ 4 School of History and Culture, Henan University, Kaifeng 475001, China; 10020112@vip.henu.edu.cn (S.L.); \\ jin@vip.henu.edu.cn (R.J.); $10020113 @ v i p . h e n u . e d u . c n(Y . S$. \\ * Correspondence: gaowenhua@henu.edu.cn
}

Citation: Li, K.; Gao, W.; Wu, L.; Hu, H.; Gong, P.; Li, S.; Jin, R.; Si, Y. Spatial Expansion of Human Settlement during the Longshan Period ( 4.5- 3.9 ka BP) and Its Hydroclimatic Contexts in the Lower Yellow River Floodplain, Eastern China. Land 2021, 10, 712. https:// doi.org/10.3390/land10070712

Academic Editors: Lei Luo, Lijun Yu, Jianguo Liu, Hui Wang, Hui Fang,

Gang Li, Hai Zhang, Jie He,

Shaohua Wang, Ruixia Yang, Peng Lu and Zhe $\mathrm{Li}$

Received: 6 June 2021

Accepted: 4 July 2021

Published: 6 July 2021

Publisher's Note: MDPI stays neutral with regard to jurisdictional claims in published maps and institutional affiliations.

Copyright: (c) 2021 by the authors. Licensee MDPI, Basel, Switzerland. This article is an open access article distributed under the terms and conditions of the Creative Commons Attribution (CC BY) license (https:// creativecommons.org/licenses/by/ $4.0 /)$.

\begin{abstract}
Obvious spatial expansion of human settlement occurred in the lower Yellow River floodplain during the Longshan period, but the external factors driving this expansion remain unclear. In this study, we first delineated the hydroclimatic changes at both regional and local scales within and around the lower Yellow River floodplain and then examined the relationships of human settlements with hydroclimatic settings between the pre-Longshan and Longshan periods. The results indicate that the site distribution, site density and hydroclimatic conditions exhibited significant shifts during the pre-Longshan and Longshan periods. In the pre-Longshan period, the intense East Asian summer monsoon and abundant monsoon-related precipitation caused widespread development of lakes and marshes in the lower Yellow River floodplain. As a result, the circumjacent highlands of the lower Yellow River floodplain contained concentrated human settlements. However, the persistent weakening of the East Asian summer monsoon and consequent precipitation decline, in conjunction with accelerated soil erosion due to decreasing forest vegetation and strengthening of human activities on the upstream Loess Plateau in the Longshan period, are likely to have jointly caused both shrinking and faster filling of preexisting lakes and marshes. Subsequently, a large area of arable land had been created in the lower Yellow River floodplain and thus was occupied by locally rapid increasing population, resulting in the notable spatial expansion of human settlements during the Longshan period.
\end{abstract}

Keywords: human settlement; spatial expansion; hydroclimatic contexts; population growth; the Longshan period; the lower Yellow River floodplain

\section{Introduction}

Human history can be understood as the history of complicated interactions between human activities and their surroundings [1-6]. These interactions have been intensively discussed worldwide in the past three decades [3-26]. Abrupt climate changes and associated dramatic environmental changes have been repeatedly suggested to be driving factors behind the rises and falls of prehistoric and historic cultures [3-6,15-26]. For example, the collapses of many agriculture-based cultures across the Northern Hemisphere at $\sim 4000$ a BP, such as the Mesopotamian [21,22], ancient Egyptian [23,24] and ancient Indian [25,26] cultures, have been attributed to abrupt climatic event occurring at $\sim 4000$ a BP. As one of the four major centers of ancient civilization, China's archaeological history has also experienced the vicissitudes of prehistoric societies [6,27-29]. Abrupt climatic changes and 
subsequent dramatic environmental changes have also been regarded as important external influencing factors $[19,20,27-30]$. It is apparent that many late Neolithic or Chalcolithic cultures across China also collapsed at $\sim 4000$ a BP, and the almost contemporaneous abrupt climatic event and associated hydrological changes could be responsible [19,20,30-38]. However, there are many studies attempting to link archaeological phenomena (i.e., cultural decline or transformation) to abrupt environmental changes, whereas relatively few studies have focused on investigating the impacts of long-term environmental evolution on the development of past human societies [6-8,19-26,30,35,36,38-41].

The crucial time of the Longshan period from $\sim 4.5$ to $\sim 3.9 \mathrm{ka}$ BP represents the initiation of state formation in China [27,28,42]. Several cultural traits marking a new stage of social development have been archaeologically confirmed in the middle and lower Yellow River reaches during the Longshan period, such as bronze smelting and widespread town-wall building [28,42]. In particular, there was an obvious spatial expansion of human settlement during the Longshan period in the lower Yellow River floodplain, as noticed by previous studies $[27,43,44]$. All of these considered variations in physical environment to be important external driving factors; however, there are apparent diverging opinions on the specific natural factor(s). Mainly based on early archaeological discoveries, Wang [43] speculated that the southward migration of the Yellow River channel during the Longshan period created a large area of arable land in the lower Yellow River floodplain for human habitation. However, other studies $[27,44]$ argued that the reduction in the size of preexisting lakes and marshes due to the long-lasting increasingly drying climate was responsible. Nonetheless, their inference bases were either from low-resolution proxy sequences with poor chronologic constraints [45] or from unconfirmed historical documents [46]. Furthermore, when these environmental changes occurred, different prehistoric societies were likely to have adopted different coping strategies as responses, which subsequently influenced social development [1-6,29]. Consequently, it is necessary to further discuss this issue to understand the patterns and mechanisms of human-environment interactions during this time interval in the lower Yellow River floodplain. Additionally, considerable advances in research on the spatial-temporal patterns of Holocene paleoenvironmental changes (especially high-resolution proxy sequences of paleoclimate) [29,47-63] and past human activities (i.e., human subsistence strategies and demographic fluctuations) $[29,64-74]$ in the lower Yellow River floodplain and the surrounding areas have been made over the past two decades. This provides a good opportunity for exploring the specific background for the abovementioned remarkable change in the spatial distribution of human settlement in the lower Yellow River floodplain during the Longshan period.

In this study, we first analyzed the changes in human settlement distribution patterns between the timespan of the immediate pre-Longshan period and the timespan of the Longshan period. Then, based on the compilation of high-resolution paleoclimatic sequences in the lower Yellow River floodplain and the surrounding areas, we attempted to delineate the hydroclimatic history of the pre-Longshan and Longshan periods for the study area at the regional scale and subsequently test the reliability of regional hydroclimatic delineation from four local paleoenvironmental records. Finally, in conjunction with local human activities, we examined the temporal and spatial differences in the relationships between the human settlements and the hydroclimatic settings.

\section{Study Area}

The lower Yellow River floodplain $\left(32^{\circ} \mathrm{N}-42^{\circ} \mathrm{N}, 112^{\circ} \mathrm{E}-122^{\circ} \mathrm{E}\right)$ is a sedimentary complex mainly composed of enormous deposits from the Yellow River and its tributaries within a Cenozoic saucer-shaped basin [75-77]. When the Yellow River enters the lower reaches carrying large quantities of silt eroded from the upstream Loess Plateau (Figure 1a), the transport capacity of the river decreases below the point where the heavy sediment load can remain in suspension, not only causing continuous and rapid aggradation of the riverbed but also resulting in frequent avulsions and channel oscillating to the north and south across the Shandong Peninsula along its course to the sea [77-79]. Specifically, 
since $\sim 500 \mathrm{BC}$, effective river-channel control measures have been taken [46,78], and the construction of artificial levees, in conjunction with the large amount of silt coming from human land use (i.e., deforestation and plowing) on the upstream Loess Plateau, has also aggravated the deposition of excessive silt in the river channel. This has irreparably elevated the riverbed and has made the river extremely prone to flooding. Therefore, changes in the landscapes of the lower Yellow River floodplain during the Holocene are closely related to the flooding and channel avulsion of the Yellow River [77-80]. In addition, the lower Yellow River floodplain was dotted with a large number of lakes and marshes throughout most of the Holocene [58,80]. Many Holocene limnetic facies were widely distributed across the lower Yellow River floodplain and the surrounding areas $[29,56-60,63,77,80]$. However, under the influences of climatic fluctuation, river flooding, and intensive agricultural activities, the locations and sizes of these lakes and marshes changed dramatically during the late Holocene $[46,58,60,80,81]$. As a result, today most of these lakes and marshes are filled with silt and have disappeared from the landscape in the lower Yellow River floodplain (Figure 1b).

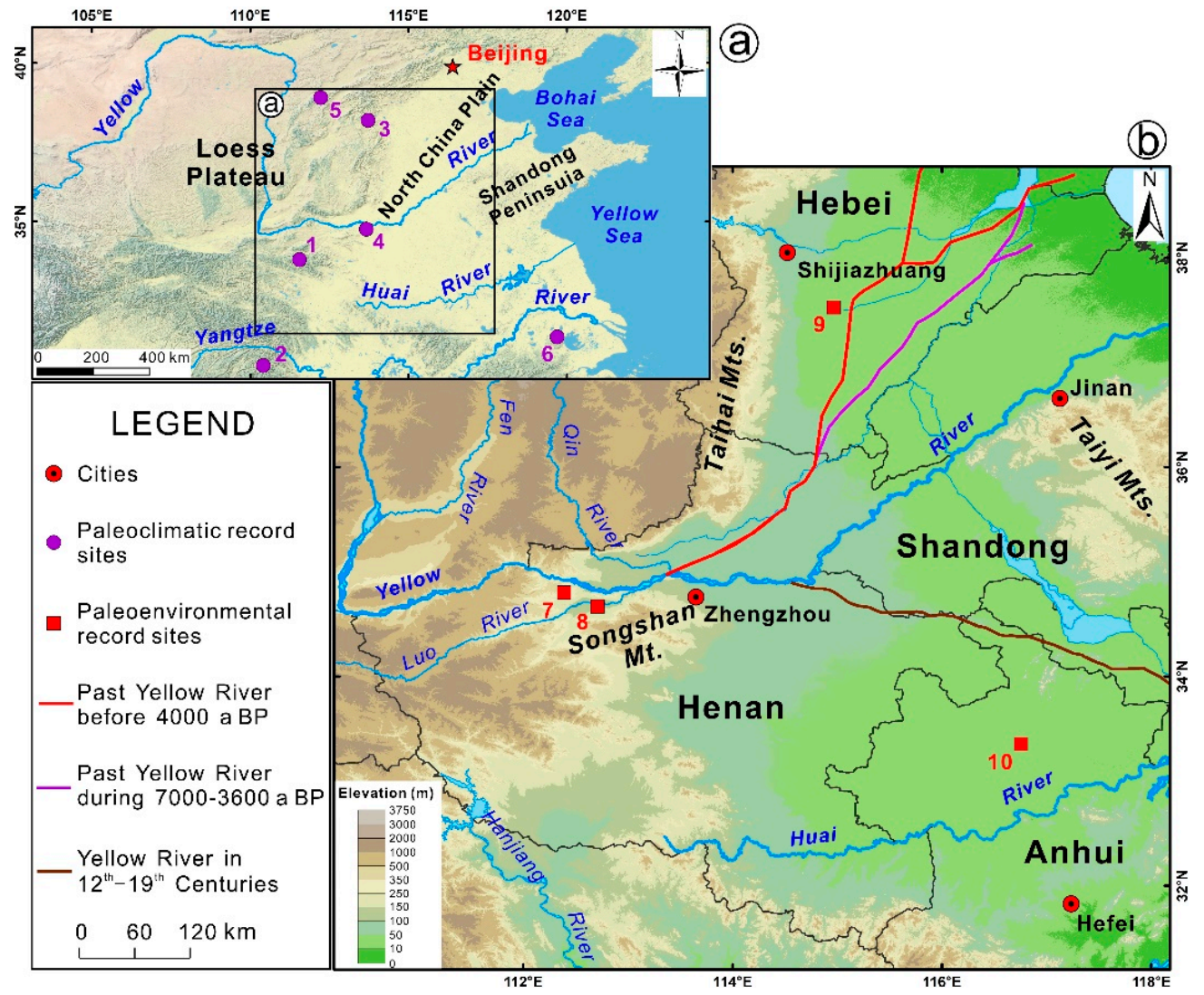

Figure 1. Study area. (a) The large-scale geographic context of the lower Yellow River floodplain. The labels are high-resolution paleoclimatic record sites (purple circles, No. 1-5) in the lower Yellow River floodplain and the surrounding areas, and they are as follows: 1. Dongshiya Cave [47], 2. Heshang Cave [48], 3. Lianhua Cave [49], 4. Zhengzhou City [50], 5. Gonghai Lake [51], and 6. Xinjie Profile (a lacustrine sequence) [52]. (b) Topographical background of the lower Yellow River floodplain and the surrounding areas and the locations of the modern Yellow River course, historic Yellow River course (12th-19th centuries) [75] and the Yellow River course during the pre-Longshan and Longshan periods. The red line is the inferred river course before $\sim 4000$ a BP from documentary records [46], and the purple line is the inferred river course between $\sim 7000$ and $~ 3600$ a BP from 157 boreholes [77]. In addition, local sites of paleoenvironmental records in the study area are also shown (red boxes, No. 7-10), including 7. Sihenan strata [53,54], 8. Wuchagou strata [55], 9. Ningjinpo strata [56], 10. Yuchisi strata [57]. 
Climatologically, the lower Yellow River floodplain is dominated by the East Asian monsoon system, with significant seasonal variations in temperature and precipitation $[76,82]$. The mean annual temperature ranges from $15{ }^{\circ} \mathrm{C}$ to $17^{\circ} \mathrm{C}$, and the mean annual precipitation ranges from $700 \mathrm{~mm}$ to $900 \mathrm{~mm}$, with most rainfall occurring during the summer [76,82]. It is noteworthy that the summer precipitation in the middle reach of the Yellow River is mainly in the form of heavy and severe rainstorms [83], and the middle reach is covered by thick loessal deposits that are readily erodible by the commonly-occurring heavy and severe rainstorms; consequently, large amounts of sediments are transported to the lower reaches of the Yellow River [76-80]. Throughout the Holocene, the East Asian summer monsoon (EASM) has experienced complex fluctuations in the lower Yellow River floodplain and the surrounding areas [47-57]. Its fluctuation and associated conspicuous environmental changes have most likely impacted the evolution of local prehistoric cultures $[11,27-30,42-45,57-63]$.

Owing to the fertile soil and water accessibility, the lower Yellow River floodplain and the surrounding areas have been believed to be a birthplace of Chinese civilization [28,42]. Continuing archaeological discoveries in recent decades have suggested that the Neolithic era began in the early Holocene, and different modern provinces in the lower Yellow River floodplain (i.e., Henan Province, southern Hebei Province, southwestern Shandong Province and northern Anhui Province, as shown in Figure 1b) show respective evolutionary trajectories of archaeological cultures (Table 1). Until now, different origin times have been defined for the early Neolithic cultures in the above four modern provinces. However, southern Hebei Province and Henan Province [42,84] have had similar archaeological cultures since the Yangshao period, and northern Anhui Province and Southwestern Shandong Province $[42,85]$ have had similar archaeological cultures since the Dawenkou period (Table 1). Furthermore, the archaeological cultures within and around the study area were almost contemporaneous during the Longshan period (Table 1).

Table 1. Neolithic cultures in the four modern provinces of the lower Yellow River floodplain and the surrounding areas.

\begin{tabular}{|c|c|c|c|c|c|c|c|}
\hline \multicolumn{2}{|c|}{ Henan Province $[28,42]$} & \multicolumn{2}{|c|}{ Southern Hebei Province [42,84] } & \multicolumn{2}{|c|}{$\begin{array}{c}\text { Southwestern Shandong } \\
\text { Province }[28,42]\end{array}$} & \multicolumn{2}{|c|}{$\begin{array}{l}\text { Northern Anhui } \\
\text { Province }[42,85]\end{array}$} \\
\hline Name & Duration (a BP) & Name & Duration (a BP) & Name & Duration (a BP) & Name & Duration (a BP) \\
\hline Lijiagou & 11000-9000 & Early Neolithic & $9000-7000$ & Houli & $8500-7500$ & Shishanzi & $8000-6500$ \\
\hline Peiligang & $9000-7000$ & Yangshao & $7000-5000$ & Beixin & $7500-6500$ & Dawenkou & $6500-4600$ \\
\hline Yangshao & $7000-5000$ & Miaodigou II & $5000-4500$ & Dawenkou & $6500-4600$ & Longshan & $4600-3900$ \\
\hline Miaodigou II & $5000-4500$ & Longshan & $4500-3900$ & Longshan & $4600-3900$ & & \\
\hline Longshan & $4500-3900$ & & & & & & \\
\hline
\end{tabular}

\section{Materials and Methods}

The archaeological data used in this study are primarily from the Atlas of the Chinese Cultural Relics for Hebei, Shandong and Anhui Provinces [86-88] and the Cultural Relics of Henan Province [89]. Moreover, some of the data are taken from relevant research papers/books and related archaeological survey/excavation reports [11,84,85,90-92]. Data from the Atlas of the Chinese Cultural Relics have been compiled based on the administrative unit of the county with a unified format and map projection. We digitized the data using ArcGIS software and positioned the locations (i.e., longitudes and latitudes) of the digitized sites. Here, it should be noted that the sites during the Longshan period were nearly synchronous in the study area; however, the archaeological cultures were different before the Longshan period in the four modern provinces (Table 1). To compare and find the differences in archaeological site distribution patterns between the time interval before the Longshan period (i.e., the pre-Longshan period) and the time interval during the Longshan period, the timespan of these two stages must first be defined. Archaeologically, Henan and southern Hebei Provinces, southwestern Shandong and northern Anhui Provinces have exhibited the same archaeological cultures since the Yangshao period and Dawenkou period, respectively (Table 1). Because the sites recorded in the Cultural Relics of Henan 
Province [89] during the Yangshao and Miaodigou II periods were not differentiated, the Yangshao and Miaodigou II periods were grouped into pre-Longshan period in these two provinces across a timespan of $\sim 7000$ and $\sim 4500$ a BP (Table 1$)$. Moreover, the Dawenkou period was selected as the pre-Longshan period ( $6500-\sim 4600$ a BP) in southwestern Shandong and north Anhui Provinces (Table 1). Although here the durations of the preLongshan period in southwestern Shandong and northern Anhui Provinces lasted for a shorter time than those in Henan and southern Hebei Provinces, the site numbers of the Beixin Culture in Shandong Province [93] and the Shishanzi Culture in Anhui Province [94] are very small. These factors do not change the overall spatial patterns of human settlement distribution during the pre-Longshan period in southwestern Shandong and northern Anhui Provinces $[93,94]$. Consequently, the different durations of the pre-Longshan period in different provinces do not influence the results, and this could serve the purpose of this study: presenting the spatial pattern differences in archaeological site distribution during the pre-Longshan and Longshan periods. In total, we gathered information on 5316 human settlement sites, including 1803 sites from the pre-Longshan period and 3513 sites from the Longshan period. Then, all the collected archaeological sites were plotted in the relief map obtained from the Shuttle Radar Topography Mission (SRTM4.1) digital elevation model (http:/ / www.gscloud.cn/) (accessed on 3 July 2021).with a spatial resolution of $30 \mathrm{~m} \times 30 \mathrm{~m}$.

Then, by using the kernel density tool of the spatial analysis module in ArcGIS software, the site distribution patterns during the pre-Longshan and Longshan periods were compared. The ArcGIS kernel density analysis is a method of converting a group of points into gratings and calculating the density of point elements around each output grating cell $[95,96]$. Conceptually, a smooth surface is fitted at each point. The surface value is highest at this point and decreases with distance increasing from the point, reaching zero at the specified search radius of the point. In this study, the default search radius recommended by ArcGIS is used. The final density at each output grating cell is then calculated by adding the values of all the kernel surfaces where they overlay the grating cell center. Consequently, the method of kernel density can visualize and interpret site clusters, and has been widely used to examine and compare the spatial changes of archaeological site distribution in many relevant studies [30,95-98]. Subsequently, the elevations of all archaeological sites during the pre-Longshan and Longshan periods were generated using the extraction tool of the spatial analysis module in ArcGIS software.

Furthermore, to analyze the relationship between human settlements and hydroclimatic settings, we first compiled six high-resolution paleoclimatic sequences in the lower Yellow River floodplain and the surrounding areas (Figure 1a) to delineate regional hydroclimatic variations in the study area during both the pre-Longshan and Longshan periods. Then, we examined the reliability of these data based on local paleoenvironmental records with relatively good age controls and identified local hydroclimatic changes during the pre-Longshan and Longshan periods. In addition, local human activities during both the pre-Longshan and Longshan periods were briefly summarized by reviewing human subsistence strategies and population changes.

\section{Results}

\subsection{Spatial Pattern Changes of Human Settlement between the Pre-Longshan and Longshan Periods}

Figure 2 shows the site distributions and the site densities during the pre-Longshan and Longshan periods. The site number (Figure 2a,b) and site density (Figure 2c,d) comparisons between the pre-Longshan and Longshan periods demonstrated several remarkable differences in archaeological site distribution. First, it is clear that there were many more Longshan sites (3513) than pre-Longshan sites (1803). Second, the areas around the Songshan Mountains were the distribution center during both the pre-Longshan and Longshan periods with two secondary high-density strips along the southeastern foothill of the Taihang Mountains and along the western fringe of the Taiyi Mountains. Third, the strips along previous Yellow River courses are the site-scarce areas during the pre-Longshan and 
Longshan periods. Fourth, the pre-Longshan sites were primarily concentrated on the highlands around the lower Yellow River floodplain (Figure 2a,c). Fifth, the Longshan sites were relatively ubiquitously spread across all landscapes in the study area (see Figure $2 b, \mathrm{~d}$ ), showing an obvious spatial expansion of human settlement in comparison with the site distribution during the pre-Longshan period.

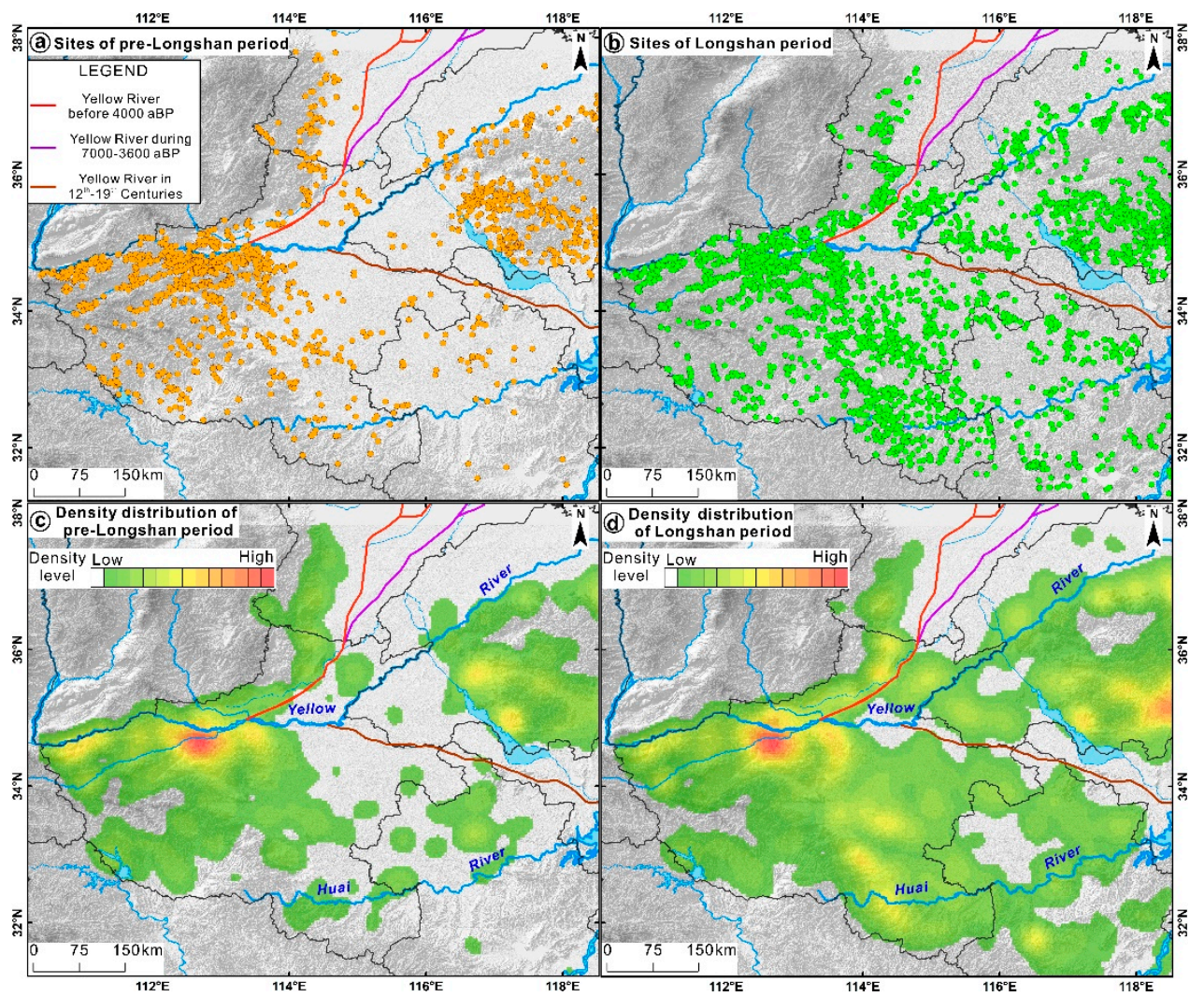

Figure 2. Human settlement distributions of the pre-Longshan period (a) and the Longshan period (b) and the site density distributions of the pre-Longshan period (c) and the Longshan period (d) in the study area.

Here, a special note is made to highlight the spatial changes in archaeological site elevation between the earlier pre-Longshan period and the later Longshan period. Table 2 shows the numbers and proportions of archaeological sites counted according to different elevations in the study area. Compared with the pre-Longshan period, the number of archaeological sites with elevations higher than $100 \mathrm{~m}$ in the Longshan period increased from 1065 to 1430 , but the percentage decreased from $59.07 \%$ to $40.72 \%$. However, both the number and percentage of archaeological sites with elevations lower than $100 \mathrm{~m}$ significantly increased from 738 to 2083 and from $41.93 \%$ to $59.28 \%$, respectively. In particular, the elevations of archaeological sites between $\sim 10 \mathrm{~m}$ and $\sim 100 \mathrm{~m}$ showed a more pronounced increase from $705(39.10 \%)$ to $1995(56.79 \%)$. These regions are only the lowlands of the study area (Figure 1b). In other words, the human settlements expanded to previous site-scarce lowlands of the lower Yellow River floodplain during the Longshan period (Figure 2b,d). 
Table 2. The elevation distribution of archaeological sites in the lower Yellow River floodplain and the surrounding areas during the pre-Longshan and Longshan periods.

\begin{tabular}{ccccc}
\hline \multirow{2}{*}{ Elevation $(\mathbf{m})$} & \multicolumn{2}{c}{ Pre-Longshan Period } & \multicolumn{2}{c}{ Longshan Period } \\
\cline { 2 - 5 } & \multicolumn{2}{c}{ Number Percent $\mathbf{( \% )}$} & \multicolumn{2}{c}{ Number Percent (\%) } \\
\hline$<10$ & 33 & 1.83 & 88 & 2.50 \\
$10-25$ & 79 & 4.38 & 227 & 6.46 \\
$25-50$ & 237 & 13.14 & 658 & 18.73 \\
$50-75$ & 12.76 & 739 & 21.04 \\
$75-100$ & 230 & 8.82 & 371 & 10.56 \\
$100-150$ & 159 & 19.36 & 576 & 16.40 \\
$150-250$ & 349 & 16.86 & 445 & 12.67 \\
$250-00$ & 304 & 16.42 & 283 & 8.06 \\
$>500$ & 296 & 6.43 & 126 & 3.59 \\
Total & 116 & 100 & 3513 & 100 \\
\hline
\end{tabular}

\subsection{Regional Hydroclimatic Changes in the Lower Yellow River Floodplain and the} Surrounding Areas

As mentioned above, to delineate the hydroclimatic characteristics during both the preLongshan and Longshan periods at the regional scale, six high-resolution proxy records with reliable chronologies and well-accepted validities of the proxy-climate or proxyenvironment relationships were selected from the lower Yellow River floodplain and the surrounding areas (Figure 1a). They include three speleothem $\delta^{18} \mathrm{O}$ datasets from Dongshiya Cave in Henan Province (Figure 3a), Heshang Cave in Hubei Province (Figure 3b), and Lianhua Cave in Shanxi Province (Figure 3c) and three reconstructed precipitation or moisture datasets from the Zhengzhou city in Henan Province (Figure 3d), Gonghai Lake in Shanxi Province (Figure 3e) and the Xinjie Profile (a lacustrine sequence) in Jiangsu Province (Figure 3f).

The speleothem $\delta^{18} \mathrm{O}$ data from Dongshiya Cave in Henan Province distinctly show that the EASM was intense from $\sim 8.0$ to $\sim 5.0 \mathrm{ka} \mathrm{BP}$ and weakened substantially between $\sim 5.0$ and $\sim 4.0 \mathrm{ka}$ BP (Figure 3a). Two other sets of $\delta^{18} \mathrm{O}$ data from Heshang Cave (Figure $3 \mathrm{~b}$ ) and Lianhua Cave (Figure 3c) also recorded nearly synchronous variations in the EASM. As a result, the regional monsoon-related precipitation or wetness shows similar variations. $\mathrm{Li}$ and Gao [50] reconstructed Holocene moisture changes in the Zhengzhou city and identified an apparent wet period between $\sim 8.0$ and $\sim 5.0 \mathrm{ka}$ BP and a subsequent clear decreasing trend in local moisture (Figure $3 \mathrm{~d}$ ). Moreover, although the fluctuation ranges are not in accordance with the moisture change in the Zhengzhou city, the reconstructed annual precipitation sequences based on pollen assemblages from Gonghai Lake in northern China (Figure 3e) and the Xinjie Profile in southern China (Figure 3f) both suggest similar variations in regional precipitation or wetness as Zhengzhou city.

In brief, at the regional scale, the six reviewed high-resolution proxy sequences indicate that the lower Yellow River floodplain and the surrounding areas experienced remarkable changes in the EASM and associated precipitation or wetness, exhibiting a wet phase from $\sim 8.0$ to $\sim 5.0 \mathrm{ka} \mathrm{BP}$ and a persistent drying phase from $\sim 5.0$ to $\sim 4.0 \mathrm{ka} \mathrm{BP}$. 


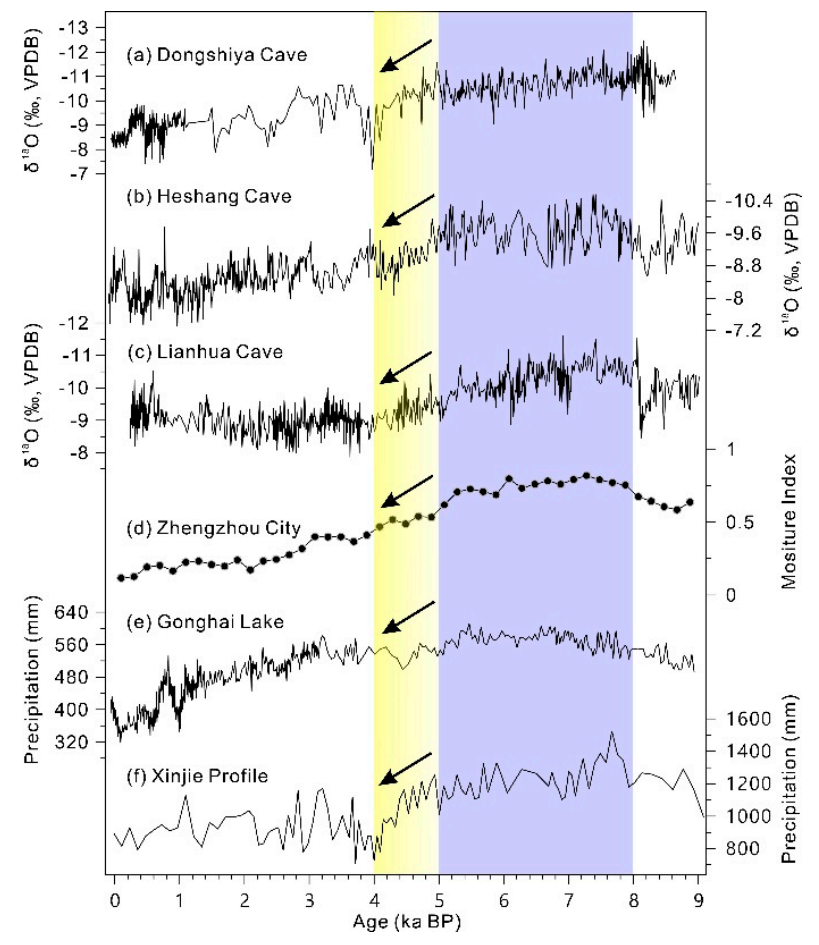

Figure 3. Proxy sequences of climatic changes within and around the study area during the past 9000 years. (a): $\delta^{18} \mathrm{O}$ sequences from Dongshiya Cave [47]; (b): $\delta^{18} \mathrm{O}$ sequences from Heshang Cave [48]; (c): $\delta^{18} \mathrm{O}$ sequences from Lianhua Cave [49]; (d): moisture index reconstruction in the Zhengzhou city [50]; (e): annual precipitation reconstruction based on pollen assemblages in Gonghai Lake [51]; (f): annual precipitation reconstruction based on pollen assemblages in the Xinjie Profile [52].

\subsection{Local Hydroclimatic Changes in the Lower Yellow River Floodplain}

To further portray local hydroclimatic changes during the pre-Longshan and Longshan periods (especially during the Longshan period) in the lower Yellow River floodplain, four paleoenvironmental records with relatively good age controls were selected (Figure 1b). They include a lacustrine sequence at Sihenan [53,54], a loess-paleosol sequence at Wuchagou [55] on western margin of the study area, a lacustrine sequence at Ningjinpo in the northern part of the study area [56], and an archaeological sequence at Yuchisi in the southern part of the study area [57].

Stratigraphically, the Sihenan section features an obviously lacustrine layer at depths from $\sim 530$ to $\sim 100 \mathrm{~cm}$, and this lacustrine layer can be further divided into four subunits: two aquatic snail rich subunits interbedded with two aquatic snail poor subunits (Figure 4, No. 7), suggesting that the area around Sihenan experienced two paleolake expansion intervals and two lake shrinking intervals between $\sim 7.0$ and $\sim 4.0 \mathrm{ka}$ BP. Based on ${ }^{14} \mathrm{C}$ dating data and cultural remains, lake development at Sihenan was interrupted by two drought events likely occurring at $\sim 5.6 \mathrm{ka}$ BP and $\sim 4.0 \mathrm{ka}$ BP $[54,99]$. In addition, the chemical index of alteration (CIA) value, which defines the weathering intensity for specific climates, clearly presents an intense weathering phase during 8-3.8 ka BP but exhibits a persistent weakening trend since $\sim 5.0 \mathrm{ka} \mathrm{BP}$ in the loess-paleosol sequence at Wuchagou (Figure 4, No. 8). This indicates that there was a warm and humid climate during 8-3.8 ka BP; however, the local climate deteriorated after $\sim 5.0 \mathrm{ka}$ BP. Similarly, the chemical weathering index (i.e., $\mathrm{C}$ index) at the Ningjinpo paleolake sequence also recorded a humid climate interval during 7.7-5.5 ka BP and a subsequent drying interval from $\sim 5.5$ to $\sim 3.3 \mathrm{ka} \mathrm{BP}$ (Figure 4, No. 9). Furthermore, the increasing trends of the Chenopodiaceae/total pollen ratio and alkane ratio also signal the aridification of local environmental conditions at Yuchisi site from $\sim 4.4$ to $\sim 4.0$ ka BP (Figure 4, No. 10). 


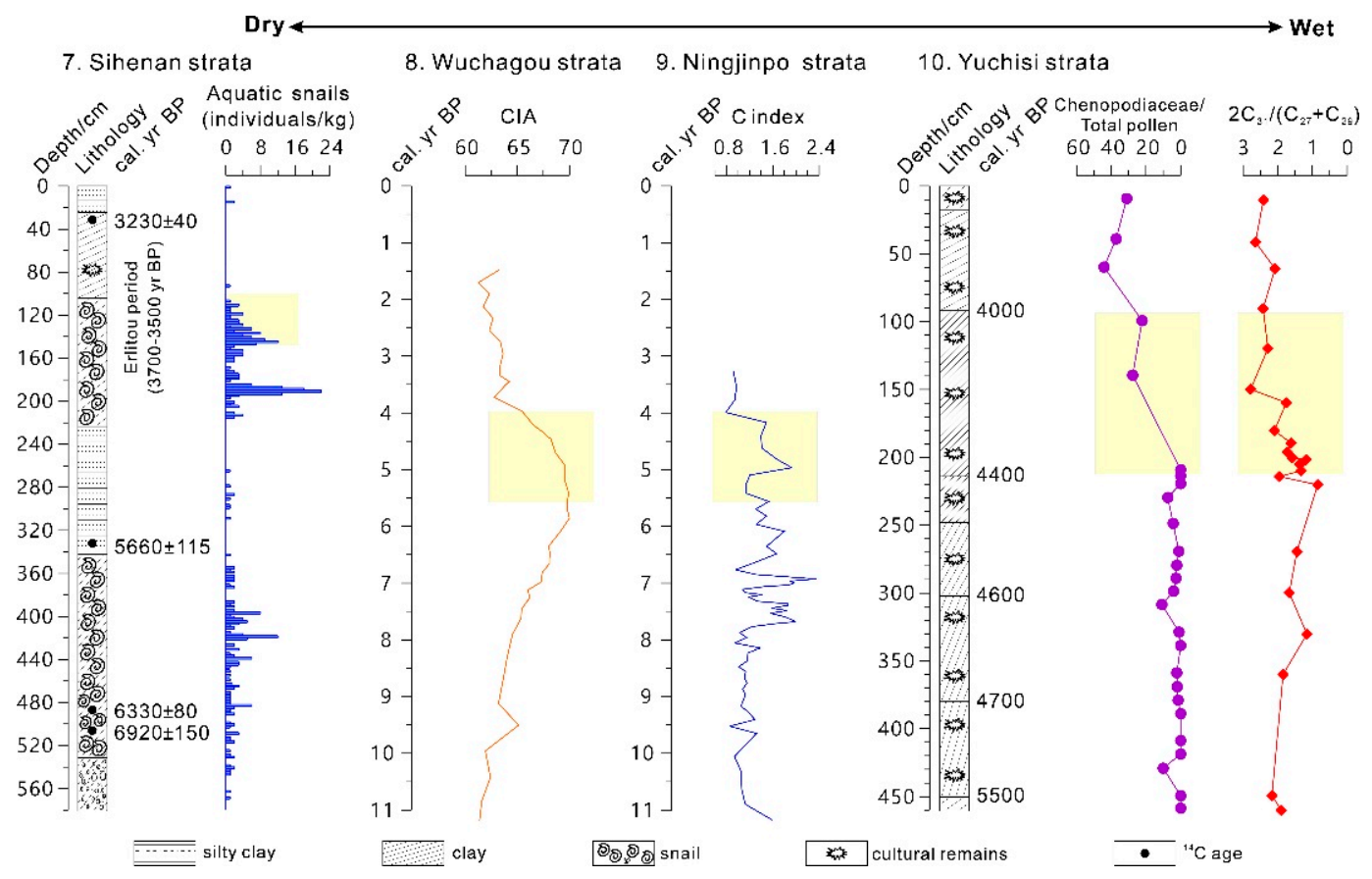

Figure 4. Local paleoenvironmental records in the study area. (7): The lithology and aquatic snails in Sihenan strata [53,54]; (8): chemical index of alteration (CIA) value in Wuchagou strata [55]; (9): C value (also a chemical weathering index to indicate climatic variation) in Ningjinpo strata [56]; (10) The ratio of Chenopodiaceae to total pollen and the alkane ratio of $2 C_{31} /\left(C_{27}+C_{29}\right)$ in Yuchisi strata [57].

In summary, the local paleoenvironmental records confirm that there was a noteworthy shift in local hydroclimatic conditions during the pre-Longshan and Longshan periods. Roughly, in the lower Yellow River floodplain, the climate was humid during the preLongshan period, whereas the local climate exhibited a lasting drying trend during the Longshan period.

\section{Discussion}

\subsection{Local Landscape Evolution in the Lower Yellow River Floodplain}

5.1.1. Local Landscape Evolution with Hydroclimatic Changes

As mentioned above, both regional paleoclimatic records (Figure 3) and local paleoenvironmental records (Figure 4) indicate that an intense EASM and associated humid climate existed during 8.0-5.0 ka BP (roughly corresponding to the pre-Longshan period) and that subsequent weakening of the EASM and consequent drying of the climate occurred during 5.0-4.0 ka BP (roughly corresponding to the Longshan period). Thus, high precipitation in the pre-Longshan period caused widespread lakes and marshes to develop not only in the lower Yellow River floodplain $[56,58,63]$ but also on the surrounding piedmont plain [100] and loess tablelands [54,58-60] around the lower Yellow River floodplain. However, with the persistent drying of local hydroclimatic conditions driven by the weakened EASM since $\sim 5.0 \mathrm{ka} \mathrm{BP}$, preexisting lakes and marshes most likely shrank first in the surrounding highlands and then in the lower Yellow River floodplain. This has been demonstrated by the three most recent studies on extensive paleoenvironmental surveys on the western margin of the study area (i.e., Zhengzhou region) [58-60], which showed that the areas of lakes and marshes in Zhengzhou region have decreased dramatically since the late Yangshao period. Consequently, a large area of arable land for prehistoric human occupation was created during the Longshan period in the lower Yellow River floodplain. Moreover, the continuous shrinking of lakes and marshes with a drying hydroclimate further led to lower base flows and subsequent river incision in the surrounding foothills of the study area $[61,62]$. 


\subsubsection{Regional Rivers and Their Possible Impacts on Local Landscape Evolution}

In the lower Yellow River floodplain, the changes in regional paleoclimate and associated hydrological changes in regional rivers (especially the Yellow River) dramatically influenced the local landscape evolution [14,30,58,60,77-80]. Wang [43] inferred that the Yellow River channel migrated southward at $\sim 4.6 \mathrm{ka} B \mathrm{BP}$ and returned to a northern position at $\sim 4.0 \mathrm{ka} \mathrm{BP}$, causing a large area of arable land formation for human occupation in the bordering areas of the present three provinces (i.e., Henan, Shandong and Anhui). However, a recent publication suggested that the Yellow River most likely flowed southward into the Yellow Sea during 3800-3500 a BP, not during the Longshan period [35]. This was further substantiated by a study on Yellow River Delta development around the Bohai Sea [101]. The authors, based on the synthesis of previously published data and a large amount of new data, concluded with a rather high level of confidence that the main course of the Yellow River emptied into the Bohai Sea from $\sim 5500$ to $~ 3600$ a BP [101]. Their conclusion is consistent with the inferred Yellow River course distributed in Hebei Province between $\sim 7000$ and $\sim 3600$ a BP (see Figure 1b) [75,77]. Therefore, the Yellow River was relatively stable and stayed in the Hebei region during both the pre-Longshan and Longshan periods (i.e., from $\sim 7000$ to $\sim 3900$ a BP, see Table 1).

However, the sediments transported by regional rivers from the upstream Loess Plateau unquestionably impacted local landscape evolution in the lower Yellow River floodplain [76-80]. The loess on the Loess Plateau is extremely vulnerable to erosion; thus, vegetation cover on the Loess Plateau is a key factor influencing loess erosion [76,78,79]. As aforementioned, the EASM weakened persistently during the interval from $\sim 5.0$ to $\sim 4.0 \mathrm{ka}$ $\mathrm{BP}$ with a conspicuous reduction in monsoon-related precipitation within and around the study area. Such precipitation or wetness variations most likely had adverse effects on vegetation development on the Loess Plateau. Two high-resolution pollen records of alpine lacustrine sequences on the Loess Plateau obviously show a nearly synchronous decrease in tree pollen proportions between $\sim 5.5$ and $\sim 4.0$ ka BP $[102,103]$. This was further supported by a recently synthesized report [104]. Sun et al. [104] used fossil pollen data from 41 sites to reconstruct the Holocene vegetation distribution in different topographic units of the Loess Plateau and found that the biome scores for forest vegetation and the proportions of forest pollen decreased synchronously between $\sim 5.5$ and $\sim 4.0 \mathrm{ka}$ BP. Moreover, the population size estimated on the basis of the number of human settlements on the Loess Plateau also shows an apparent increase during the Longshan period $[34,96,105,106]$. Consequently, decreasing forest vegetation [102-104], intensifying human activities [34,96,105,106] and local summer precipitation primarily in the form of heavy and severe rainstorms [83], might have collectively resulted in more soil erosion and heavier sediment loads in the rivers flowing through the Loess Plateau. As a result, accelerated sedimentation rate occurred from $\sim 5.0$ to $\sim 3.0 \mathrm{ka} \mathrm{BP}$ in the lower Yellow River floodplain $[107,108]$ and the sedimentation rate had increased from $\sim 3.6 \mathrm{~mm} / \mathrm{yr}$ to $\sim 6.4 \mathrm{~mm} / \mathrm{yr}$ [108]. This would have inevitably filled the preexisting lakes and marshes more quickly and subsequently caused the formation of more arable land in the lower Yellow River floodplain.

\subsection{Human Subsistence Strategies and Population Changes in the Lower Yellow River Floodplain}

The interactions between prehistoric societies and environmental changes are quite complex [1-6]. Human subsistence strategies are sensitive to changing environmental conditions, thus, understanding human subsistence strategies and adaptations in prehistory thus is crucial to reveal the human-environment interactions $[6,27,29,42]$. Archaeobotanical research has reported that the main source of plant foods was primarily provided by agriculture with a mixed millet-rice farming mode as the distinct characteristic of regional subsistence strategy in and around the lower Yellow River floodplain during both the preLongshan and Longshan periods [64-73]. However, there are obvious regional differences of this mixed millet-rice farming mode in the study area. During the pre-Longshan period, flotation results revealed that the millet (including foxtail millet and broomcorn millet) occupied the dominant position in human diet, but its proportion is higher in the sites located 
on surrounding hills and loess tablelands than the sites located on alluvial plains [64,66-68], that is, the proportion of rice is higher in the low-lying alluvial plains [67-70]. Subsequently, this pattern had not substantially changed in the Longshan period, but spatial range of mixed millet-rice farming mode had shrunk toward alluvial plains, showing millet agriculture in the hills and loess tablelands and mixed millet-rice farming in the alluvial plains and low-lying hills and loess tablelands, respectively [66-70,72]. In addition, although there were many more Longshan sites than pre-Longshan sites in the study area (Figure 2a,b), the reconstructed curves of prehistorical population clearly exhibited more detailed demographic fluctuations, with two peaks (5600-5000 a BP, 4300-4000 a BP) and two declines (5000-4500 a BP and 4000-3900 a BP) of regional population during both the per-Longshan and Longshan periods $[29,74]$.

\subsection{Human Responses to Hydroclimatic Changes in the Lower Yellow River Floodplain}

As stated earlier, the EASM was strong, and monsoon-related precipitation was high from $\sim 8.0$ to $\sim 5.0 \mathrm{ka}$ BP within and around the lower Yellow River floodplain (Figure 3). Thus, widespread development of lakes and marshes existed in the study area $[54,56,58-60,63]$ due to the preexisting saucer-shaped topography $[76,80]$. Such hydroclimatic conditions were suitable for cultivating rice, resulting in charred rice found widely in the sites across the study area [64-68], whereas the extensive development of lakes and marshes in the lower Yellow River floodplain is also likely to have hindered prehistoric human occupation in the lowlands. Consequently, only some sporadic highlands might have existed for humans dwelling in the lower Yellow River floodplain (Figure 2a,c). The broad highlands around the study area featured a high concentration of human settlements during the pre-Longshan period (see Figure 2a,c).

Since $\sim 5.0 \mathrm{ka} \mathrm{BP}$, with the persistent weakening of the EASM and associated precipitation decline, the hydroclimatic conditions in the lower Yellow River floodplain and the surrounding areas presented drying trends (Figures 3 and 4), causing obvious shrinking of lakes and marshes on the broad highlands and transitional regions between highlands and lowlands around the lower Yellow River floodplain since the late Yangshao period [58-60]. Moreover, as mentioned above, although the main channel of the Yellow River was stable and stayed on the North China Plain in Hebei Province from $~ 7.0$ to $\sim 3.6 \mathrm{ka}$ BP $[35,75,77,101]$, persistent deterioration of regional hydroclimatic conditions and strengthening of human activities during the Longshan period jointly accelerated soil erosion on the upstream Loess Plateau. As a result, more sediments were transported by the Yellow River and other regional rivers to the downstream alluvial plains (i.e., the lower Yellow River floodplain), leading to faster filling of preexisting lakes and marshes and the formation of a large area of arable land in the lower Yellow River floodplain (see Section 5.1.2). Consequently, the local deteriorating hydroclimatic conditions might have adverse effects on the mixed millet-rice farming mode and caused rice proportion decline in the crop structure of surrounding highlands during the Longshan period [66-70,72]. Meanwhile, the rapid increasing population during $\sim 4300-\sim 4000$ a BP in the study area $[29,74]$ is likely to have jointly driven some prehistoric humans to migrate toward these newly formed arable land. Subsequently, human settlements were ubiquitously spread across all landscapes, showing distinct spatial expansion of human settlement in the lower Yellow River floodplain during the Longshan period (see Figure 2b,d).

\section{Conclusions}

By comparing the spatial and temporal changes in human settlements and hydroclimatic settings during the pre-Longshan and Longshan periods in the lower Yellow River floodplain, the following conclusions can be drawn.

(1) The archaeological site distribution patterns were visibly different between the preLongshan period and the Longshan period. The pre-Longshan sites were primarily concentrated in the western highlands with two secondary strips along the southeastern foothills of the Taihang Mountains and the western fringe of the Taiyi Mountains, 
and only a few sites were dispersed in the lower Yellow River floodplain. In contrast, the Longshan sites were nearly ubiquitously spread across all landscapes within and around the lower Yellow River floodplain.

(2) There were two evolutionary phases of the EASM and associated monsoon-related precipitation or wetness during the pre-Longshan and Longshan periods within and around the lower Yellow River floodplain: the EASM experienced a strong and wet phase between $\sim 8.0$ and $\sim 5.0 \mathrm{ka} \mathrm{BP}$ and subsequently weakened, resulting in a drier phase between $\sim 5.0$ and $\sim 4.0 \mathrm{ka}$ BP.

(3) Although the lower Yellow River channel was stable and stayed in the Hebei region of the North China Plain during the Longshan period, decreasing forest vegetation and intensifying human activities under the background of persistent drying of the hydroclimatic conditions since $\sim 5.0 \mathrm{ka}$ BP most likely caused more soil erosion and subsequent heavier sediment loads in the rivers flowing through the Loess Plateau, resulting in faster filling of preexisting lakes and marshes in the lower Yellow River floodplain.

(4) The hydroclimatic variations in the lower Yellow River floodplain influenced human settlement distribution patterns during the pre-Longshan and Longshan periods. Under overall wet hydroclimatic conditions, lakes and marshes developed widely in the lower Yellow River floodplain and the surrounding highlands during the preLongshan period. However, persistent deterioration of local hydroclimatic settings and faster silt filling during the Longshan period caused preexisting lakes and marshes to shrink dramatically. Consequently, the pre-Longshan sites were concentrated in the circumjacent highlands; whereas the newly formed land during the Longshan period were likely to have been occupied by the rapidly increasing population who adopted the mixed millet-rice farming mode, resulting in distinct spatial expansion of human settlement in the lower Yellow River floodplain.

Author Contributions: Conceptualization, K.L., W.G., and L.W.; methodology, K.L., W.G., S.L., R.J., Y.S.; software, H.H., P.G.; writing-original draft preparation, K.L., W.G.; writing-review and editing, K.L., W.G., L.W., H.H., P.G., S.L., R.J., Y.S.; funding acquisition, K.L., W.G. All authors have read and agreed to the published version of the manuscript.

Funding: This research was funded by the National Key Research and Development Program of China (No. 2020YFC1521605), the National Natural Science Foundation of China (Nos. 41701009 and 41501214), the MOE Youth Foundation of Humanities and Social Sciences, China (No. 17YJCZH046), and the Foundation of Humanities and Social Sciences of the Department of Education, Henan Province, China (Nos. 2018-ZZJH-086 and 2019-ZZJH-103).

Acknowledgments: We are grateful to two anonymous reviewers for their constructive comments and suggestions.

Conflicts of Interest: The authors declare no conflict of interest.

\section{References}

1. Redman, C.L. Resilience theory in archaeology. Am. Anthropol. 2005, 107, 70-77. [CrossRef]

2. Folke, C. Resilience: The emergence of a perspective for social-ecological systems analysis. Glob. Environ. Chang. 2006, 16, 253-267. [CrossRef]

3. Butzer, K.W. Collapse, environment, and society. Proc. Natl. Acad. Sci. USA 2012, 109, 3632-3639. [CrossRef]

4. Brooke, J.L. Climate Change and the Course of Global History: A Rough Journey; Cambridge University Press: Cambridge, UK, 2014.

5. Qin, Z. Exploring the early Anthropocene: Implications from the long-term human-climate interactions in early China. Mediterr. Archaeol. Archaeom. 2021, 21, 133-148.

6. Dong, G.H.; Li, R.; Lu, M.X.; Zhang, D.J.; James, N. Evolution of human-environmental interactions in China from the Late Paleolithic to the Bronze Age. Prog. Phys. Geogr. 2020, 44, 233-250. [CrossRef]

7. Stanley, D.J.; Chen, Z.Y.; Song, J. Inundation, sea-level rise and transition from Neolithic to Bronze Age cultures, Yangtze Delta, China. Geoarchaeology 1998, 14, 15-26. [CrossRef]

8. Sandweiss, D.H.; Maasch, K.A.; Anderson, D.G. Transitions in the Mid-Holocene. Science 1999, 283, 499-500. [CrossRef]

9. Oğuz-Kırca, E.D.; Liritzis, I. Reemergence of Atlantis: The shifting paradigm and creation of neo-spatial models. Sci. Cult. 2019, 5, 69-88. 
10. Li, K.F.; Zhu, C.; Jiang, F.Q.; Li, B.; Wang, X.H.; Cao, B.; Zhao, X.F. Archaeological sites distribution and its physical environmental settings between ca 260-2.2 ka BP in Guizhou Privince, Southwest China. J. Geogr. Sci. 2014, 24, 526-538. [CrossRef]

11. Wu, L.; Zhou, H.; Li, J.Y.; Li, K.F.; Sun, X.L.; Lu, S.G.; Li, L.Y.; Zhu, T.X.; Guo, Q.C. Thiessen polygon analysis and spatial pattern evolution of Neolithic cultural sites (8.0-4.0 ka BP) in Huaibei Plain of Anhui, East China. Quat. Int. 2019, 521, 75-84. [CrossRef]

12. Shqiarat, M. History and archaeology of water management in Jordan through ages. Sci. Cult. 2019, 5, 51-54.

13. Wu, L.; Lu, S.G.; Zhu, C.; Ma, C.M.; Sun, X.L.; Li, X.X.; Li, C.C.; Guo, Q.C. Holocene environmental archaeology of the Yangtze River Valley in China: A review. Land 2021, 10, 302. [CrossRef]

14. Storozum, M.; Liu, H.W.; Qin, Z.; Ming, K.D.; Fu, K.; Wang, H.; Kidder, T. Early evidence of irrigation technology in the North China Plain: Geoarchaeological investigations at the Anshang Site, Neihuang County, Henan Province, China. Geoarchaeology 2018, 33, 143-161. [CrossRef]

15. Binford, M.W.; Kolata, A.L.; Brenner, M.; Janusek, J.W.; Seddon, M.T.; Abbott, M.; Curtis, J.H. Climate variation and the rise and fall of an Andean civilization. Quat. Res. 1997, 47, 235-248. [CrossRef]

16. Hodell, D.A.; Curtis, J.H.; Brenner, M. Possible role of climate in the collapse of classic Maya civilization. Nature 1995, 375, 391-394. [CrossRef]

17. deMenocal, P.B. Cultural responses to climate change during the late Holocene. Science 2001, 292, 667-673. [CrossRef]

18. Haug, G.H.; Günther, D.; Peterson, L.C.; Sigman, D.M.; Hughen, Y.R.; Aeschlimann, B. Climate and the collapse of Maya civilization. Science 2003, 299, 1731-1735. [CrossRef] [PubMed]

19. Wu, W.X.; Liu, T.S. Possible role of the "Holocene event 3" on the collapse of Neolithic cultures around the central plain of China. Quat. Int. 2004, 117, 153-166.

20. Liu, F.G.; Feng, Z.D. A dramatic climatic transition at 4000 cal. yr BP and its cultural responses in Chinese cultural domains. Holocene 2012, 22, 1181-1197. [CrossRef]

21. Weiss, H.; Courty, M.A.; Wetterstrom, W.; Guichard, F.; Senior, L.; Meadow, R.; Crunow, A. The genesis and collapse of third millennium north Mesopotamian civilization. Science 1993, 261, 995-1004. [CrossRef] [PubMed]

22. Cullen, H.M.; deMenocal, P.B.; Hemming, S.; Hemming, G.; Brown, F.H.; Guilderson, T.; Sirocko, F. Climate change and the collapse of the Akkadian empire: Evidence from the deep sea. Geology 2000, 28, 379-382. [CrossRef]

23. Stanley, J.D.; Krom, M.D.; Cliff, R.A.; Woodward, J.C. Nile flow failure at the end of the Old Kingdom, Egypt: Strontium isotopic and petrologic evidence. Geoarchaeology 2003, 18, 395-402. [CrossRef]

24. Drysdale, R.; Zanchetta, G.; Hellstrom, J.; Maas, R.; Fallick, A.; Pickett, M.; Cartwright, I.; Piccini, L. Late Holocene drought responsible for the collapse of Old World civilization is recorded in an Italian cave flowstone. Geology 2006, 34, 101-104. [CrossRef]

25. Staubwasser, M.; Sirocko, F.; Grootes, P.M.; Segl, M. Climate change at the $4.2 \mathrm{ka}$ BP termination of the Indus valley civilization and Holocene south Asian monsoon variability. Geophys. Res. Lett. 2003, 30, 1425. [CrossRef]

26. Sengupta, T.; Mukherjee, A.D.; Bhushan, R.; Ram, F.; Bera, M.K.; Raj, H.; Dabhi, A.J.; Bisht, R.S.; Rawat, Y.S.; Bhattacharya, S.K.; et al. Did the Harappan settlement of Dholavira (India) collapse during the onset of Meghalayan stage drought? J. Quat. Sci. 2020, 25, 382-395. [CrossRef]

27. Liu, L. The Chinese Neolithic: Trajectories to Early States; Cambridge University Press: Cambridge, UK, 2004.

28. Underhill, A.P. A Companion to Chinese Archaeology; John Wiley \& Sons: Hoboken, NJ, USA, 2013.

29. Ren, X.L.; Xu, J.J.; Wang, H.; Storozum, M.; Lu, P.; Mo, D.W.; Li, T.Y.; Xiong, J.G.; Kidder, T.R. Holocene fluctuations in vegetation and human population demonstrate social resilience in the prehistory of the Central Plains of China. Environ. Res. Lett. 2021, 15, 055030. [CrossRef]

30. Li, K.F.; Gao, W.H. Human settlement distribution patterns during the Longshan and Xinzhai-Erlitou periods and their hydrogeomorphic contexts in the Central Plains, China. Catena 2021, 204, 105433. [CrossRef]

31. An, C.B.; Tang, L.Y.; Barton, L.; Chen, F.H. Climate change and cultural response around 4000 cal yr B.P. in the western part of Chinese Loess Plateau. Quat. Res. 2005, 63, 347-352. [CrossRef]

32. Huang, C.C.; Pang, J.L.; Zha, X.C.; Su, H.X.; Jia, Y.F.; Zhu, Y.Z. Impact of monsoonal climatic change on Holocene overbank flooding along Sushui River, middle reach of the Yellow River, China. Quat. Sci. Rev. 2007, 26, 2247-2264. [CrossRef]

33. Huang, C.C.; Pang, J.L.; Zha, X.C.; Su, H.X.; Jia, Y.F. Extraordinary floods related to the climatic event at 4200 a BP on the Qishuihe River, middle reaches of the Yellow River, China. Quat. Sci. Rev. 2011, 30, 460-468. [CrossRef]

34. Cui, J.X.; Sun, Z.Y.; Burr, G.S.; Shao, J.; Chang, H. The great cultural divergence and environmental background of Northern Shaanxi and its adjacent regions during the late Neolithic. Archaeol. Res. Asia 2019, 20, 100164. [CrossRef]

35. Yu, S.Y.; Hou, Z.F.; Chen, X.X.; Wang, Y.X.; Song, Y.G.; Gao, M.K.; Pan, J.R.; Sun, M.; Fang, H.; Han, J.Y.; et al. Extreme flooding of the lower Yellow River near the Northgrippian-Meghalayan boundary: Evidence from the Shilipu archaeological site in southwestern Shandong Province, China. Geomorphology 2020, 350, 106878. [CrossRef]

36. Wang, W. Discussion on the large-scale cultural changes at 2000 BC in China. Archaeology 2004, 1, 67-77. (In Chinese)

37. Zhang, J.N.; Xia, Z.K. Deposition evidence of the 4 ka BP flood events in central China plains. Acta Geogr. Sin. 2011, 66, 685-697, (In Chinese with English Abstract).

38. Sun, Q.L.; Liu, Y.; Wünnemann, B.; Peng, Y.J.; Jiang, X.Z.; Deng, L.J.; Chen, J.; Li, M.T.; Chen, Z.Y. Climate as a factor for Neolithic cultural collapses approximately 4000 years BP in China. Earth-Sci. Rev. 2019, 197, 102915. [CrossRef]

39. Dong, G.H.; Liu, F.W.; Yang, Y.S.; Wang, L.; Chen, F.H. Cultural expansion and its influencing factors during Neolithic period in the Yellow River valley, northern China. Chin. J. Nat. 2016, 38, 248-252, (In Chinese with English Abstract). 
40. Zhang, Z.P.; Liu, J.B.; Chen, J.; Chen, S.Q.; Shen, Z.W.; Chen, J.; Liu, X.K.; Wu, D.; Sheng, Y.W.; Chen, F.H. Holocene climatic optimum in the East Asian monsoon region of China defined by climatic stability. Earth Sci. Rev. 2021, 212, 103450. [CrossRef]

41. Jaffe, Y.Y.; Castellano, L.; Shelach-Lavi, G.; Campbell, R.B. Mismatches of scale in the application of paleoclimatic research to Chinese archaeology. Quat. Res. 2021, 99, 14-33. [CrossRef]

42. Liu, L.; Chen, X.C. The archaeology of China: From the Late Paleolithic to the Early Bronze Age; Cambridge University Press: Cambridge, UK, 2012.

43. Wang, Q. Preliminary discussion on the prehistoric diversion of lower Yellow River channel and its relations with cultural development. Cult. Relics Cent. China 1993, 4, 65-74. (In Chinese)

44. Chen, H.B. Settlements distribution and its relations with environmental changes in the Shandong-Henan-Anhui cultural region. Archaeology 2007, 2, 48-60. (In Chinese)

45. Cao, B.W. Study of environmental archaeology in the Huixian and sourrounding areas. Huaxia Archaeol. 1994, 3, 61-67. (In Chinese)

46. Zou, Y.L. The History Geography of Huanghuaihai Plain; Anhui Educational Publishing House: Hefei, China, 1993. (In Chinese)

47. Zhang, N.; Yang, Y.; Cheng, H.; Zhao, J.Y.; Yang, X.L.; Liang, S.; Nie, X.D.; Zhang, Y.H.; Edwards, R.L. Timing and duration of the East Asian summer monsoon maximum during the Holocene based on stalagmite data from North China. Holocene 2018, 28, 1631-1641. [CrossRef]

48. Hu, C.Y.; Henderson, G.M.; Huang, J.H.; Xie, S.C.; Sun, Y.; Johnson, K.R. Quantification of Holocene Asian monsoon rainfall from spatially separated cave records. Earth Planet. Sci. Lett. 2008, 266, 221-232. [CrossRef]

49. Dong, J.G.; Shen, C.C.; Kong, X.G.; Wu, C.C.; Hu, H.M.; Ren, H.J.; Wang, Y. Rapid retreat of the East Asian summer monsoon in the middle Holocene and a millennial weak monsoon interval at 9 ka in northern China. J. Asian Earth Sci. 2018, 151, 31-39. [CrossRef]

50. Li, K.F.; Gao, W.H. Holocene climate change in Henan area: A synthesis of proxy records. Quat. Int. 2019, 521, 185-193. [CrossRef]

51. Chen, F.H.; Xu, Q.H.; Chen, J.H.; Birks, H.J.B.; Liu, J.B.; Zhang, S.R.; Jin, L.Y.; An, C.B.; Telford, R.J.; Cao, X.Y.; et al. East Asian summer monsoon precipitation variability since the last deglaciation. Sci. Rep. 2015, 5, 11186. [CrossRef]

52. Lu, F.Z.; Ma, C.M.; Zhu, C.; Lu, H.Y.; Zhang, X.J.; Huang, K.Y.; Guo, T.H.; Li, K.F.; Li, L.; Li, B.; et al. Variability of East Asian summer monsoon precipitation during the Holocene and possible forcing mechanisms. Clim. Dyn. 2019, 52, 969-989. [CrossRef]

53. Liang, L.; Xia, Z.K.; Liu, D.C. Reconstruction of the palaeoenvironment in central north China during 5000 a BP to 4000 a BP. Acta Sci. Nat. Univ. Pekin. 2003, 39, 532-537, (In Chinese with English Abstract).

54. Dong, G.H.; Xia, Z.K.; Elston, R.; Sun, X.W.; Chen, F.H. Response of geochemical records in lacustrine sediments to climate change and human impact during middle Holocene in Menjin, Henan Province, China. Front. Earth Sci. China 2009, 3, $279-285$. [CrossRef]

55. Jia, Y.N.; Zhang, Y.Z.; Wang, N.L.; Huang, C.C.; Qiu, H.J.; Wang, H.Y.; Yu, Y.K.; Seilbike, A.; Zou, M.B.; Lin, X.; et al. Chronostratigraphic framework and paleoenvironmental interpretation of the Holocene loess-paleosol sequence in the Luoyang Basin, Central China. Aeolian Res. 2021, 48, 100657. [CrossRef]

56. Li, C.Z.; Li, B.; Li, Y.C.; Chen, B.S.; Xu, Q.H.; Zhang, W.S.; Liu, W.; Ding, G.Q. Variation of summer monsoon intensity in the North China Plain and its response to abrupt climatic events during the early-middle Holocene. Quat. Int. 2020, 550, 66-73. [CrossRef]

57. Wang, J.J.; Sun, L.G.; Chen, L.Q.; Xu, L.B.; Wang, Y.H.; Wang, X.M. The abrupt climate change near 4400 yr BP on the cultural transition in Yuchisi, China and its global linkage. Sci. Rep. 2016, 6, 27723. [CrossRef] [PubMed]

58. Yu, G. Sedimentology of Lake-River Systems and Environmental Evolution in Zhengzhou Region; Science Press: Beijing, China, 2016. (In Chinese)

59. Li, S.Q.; Ma, Y.F.; Guo, Y.S.; Du, J.; Wang, D.F. Relationship between distribution features of ancient settlement and changes of river and lake prior to western Zhou danasty in Zhegnzhou area. Areal Res. Dev. 2019, 38, 171-176, (In Chinese with English Abstract).

60. Lu, P.; Lü, J.Q.; Zhuang, Y.J.; Chen, P.P.; Wang, H.; Tian, Y.; Mo, D.W.; Xu, J.J.; Gu, W.F.; Hu, Y.Y.; et al. Evolution of Holocene alluvial landscapes in the northeastern Songshan region, Central China: Chronology, models and socio-economic impact. Catena 2021, 197, 104956. [CrossRef]

61. Rosen, A.M. The impact of environmental change and human land use on alluvial valleys in the Loess Plateau of China during the Middle Holocene. Geomorphology 2008, 101, 298-307. [CrossRef]

62. Lu, P.; Wang, H.; Chen, P.P.; Storozum, M.J.; Xu, J.J.; Tian, Y.; Mo, D.W.; Wang, S.Z.; He, Y.; Yan, L.J. The impact of Holocene alluvial landscape evolution on an ancient settlement in the southeastern piedmont of Songshan Mountain, Central China: A study from the Shiyuan site. Catena 2019, 183, 104232. [CrossRef]

63. Jiang, S.W.; Luo, W.H.; Tu, L.Y.; Yu, Y.Y.; Fang, F.; Liu, X.Y.; Zhan, T.; Fang, L.D.; Zhang, X.L.; Zhou, X. The Holocene optimum (HO) and the response of human activity: A case study of the Huai River Basin in eastern China. Quat. Int. 2018, 493, 31-38. [CrossRef]

64. Wang, C.; Lu, H.Y.; Zhang, J.P.; Gu, Z.Y.; He, K.Y. Prehistoric demographic fluctuations in China inferred from radiocarbon data and their linkage with climate change over the past 50,000 years. Quat. Sci. Rev. 2014, 98, 45-59. [CrossRef]

65. Yuan, J. Research on Subsistence from the Neolithic to the Bronze Age in China; Fudan University Press: Shanghai, China, 2019. (In Chinese) 
66. Zhao, Z.J. The process of origin of agriculture in China: Archaeological evidence from the flotation results. Quat. Sci. 2014, 34, 73-84, (In Chinese with English Abstract).

67. Liao, Y.N.; Lu, P.; Mo, D.W.; Wang, H.; Storozum, M.J.; Chen, P.P.; Xu, J.J. Landforms influence the development of ancient agriculture in the Songshan area, central China. Quat. Int. 2019, 521, 85-89. [CrossRef]

68. Yang, Y.Z.; Cheng, Z.J.; Yao, L.; Li, Z.Y.; Li, W.Y.; Luo, W.H.; Yuan, Z.J.; Zhang, J.; Zhang, J.Z. The emergence, development and regional differences of mixed farming of rice and millet in the upper and middle Huai River Valley, China. Sci. China Earth Sci. 2016, 59, 1779-1790. [CrossRef]

69. Yang, L.; Ma, M.M.; Chen, T.T.; Cui, Y.F.; Chen, P.P.; Zheng, L.C.; Lu, P. How did trans-Eurasian exchanges affect spatial-temporal variation in agricultural patterns during the late prehistoric period in the Yellow River valley (China)? Holocene 2021, 31, 247-257. [CrossRef]

70. Lee, G.A.; Crawford, G.W.; Liu, L.; Chen, X.C. Plants and people from the Early Neolithic to Shang periods in North China. Proc. Natl. Acad. Sci. USA 2007, 104, 1087-1092. [CrossRef] [PubMed]

71. Zhang, J.N.; Xia, Z.K.; Zhang, X.H. Research on charred plant remains from the Neolithic to the Bronze Age in Luoyang Basin. Chin. Sci. Bull. 2014, 59, 3388-3397. (In Chinese) [CrossRef]

72. Jin, G.Y.; Wagner, M.; Tarasov, P.E.; Wang, F.; Liu, Y.C. Archaeobotanical records of Middle and Late Neolithic agriculture from Shandong Province, East China, and a major change in regional subsistence during the Dawenkou Culture. Holocene 2016, 26, 1605-1615. [CrossRef]

73. Jin, G.Y. A study on the diet of the Longshan culture residents. J. Lit. Hist. Philos. 2013, 2, 99-111, (In Chinese with English Abstract).

74. Cheung, C.; Zhang, H.; Hepburn, J.C.; Yang, D.Y.; Richards, M.P. Stable isotope and dental caries data reveal abrupt changes in subsistence economy in ancient China in response to global climate change. PLoS ONE 2019, 14, e0218943.

75. Tan, Q.X. The lower course of the Yellow River before the western Han dynasty. Hist. Geogr. 1980, 1, 48-64. (In Chinese)

76. Zhao, S.Q. The Physical Geography of China; Wiley: New York, NY, USA, 1986.

77. Wu, C.; Xu, Q.; Zhang, X.; Ma, Y. Study on the Palaeochannel in the North China Plain; China Science and Technology Press: Beijing, China, 1991. (In Chinese)

78. Chen, Y.Z.; Syvitski, J.P.M.; Gao, S.; Overeem, I.; Kettner, A.J. Socio-economic impacts on floodings: A 4000-year history of the Yellow River, China. Ambio 2012, 41, 682-698. [CrossRef]

79. Kidder, T.R.; Liu, H.W.; Xu, Q.H.; Li, M.L. The alluvial geoarchaeology of the Sanyangzhuang site on the Yellow River floodplain, Henan Province, China. Geoarchaeology 2012, 27, 324-343. [CrossRef]

80. Guo, S.Y.; Yan, G.S.; Xue, D.; Zhang, E.H.; Zhang, S.; Chen, C.S. Study of Stratigraphic Paleontology in Henan Province; The Yellow River Water Conservancy Press: Zhengzhou, China, 2008; Volume 7. (In Chinese)

81. Wang, L.S.; Hu, S.Y.; Yu, G.; Wang, X.H.; Wang, Q.; Zhang, Z.H.; Ma, M.M.; Cui, B.L.; Liu, X.B. Multiproxy studies of lake sediments during mid-Holocene in Zhengzhou region of the Henan Province, central China, and the implications for reconstructing the paleoenvironments. Quat. Int. 2019, 521, 104-110. [CrossRef]

82. Wang, S.W.; Li, W.J. Climate of China; China Meteorological Press: Beijing, China, 2007.

83. Ran, Q.H.; Zong, X.Y.; Ye, S.; Gao, J.H.; Hong, Y.Y. Dominant mechanism for annual maximum flood and sediment events generation in the Yellow River basin. Catena 2020, 187, 104376. [CrossRef]

84. Zhang, C.L.; Duan, H.Z. The Cultural Corridor Between the Central Plains and Northern Area in China; Cultural Relics Press: Beijing, China, 2015. (In Chinese)

85. Xu, F. A Transitional Region: A Research on the Early Social Process of Lianghuai Region; Shanghai Classics Publishing House: Shanghai, China, 2020. (In Chinese)

86. Bureau of National Cultural Relics. Atlas of Chinese Cultural Relics-Hebei Volume; Cultural Relics Press: Beijing, China, 2013. (In Chinese)

87. Bureau of National Cultural Relics. Atlas of Chinese Cultural Relics-Shandong Volume; SinoMaps Press: Beijing, China, 2007. (In Chinese)

88. Bureau of National Cultural Relics. Atlas of Chinese Cultural Relics-Anhui Volume; SinoMaps Press: Beijing, China, 2014. (In Chinese)

89. Henan Provincial Adiministration of Cultural Heritage. Cultural Relics of Henan Province; Wenxin Press: Zhengzhou, China, 2008. (In Chinese)

90. Zhengzhou Municipal Institute of Archaeology, School of Archaeology and Museology in Peking University. Archaeological survey report of Suo-Xu-Ku River basins in Zhengzhou Region, Henan Province. Anc. Civiliz. 2016, 10, 301-375. (In Chinese)

91. Institute of Archaeology in Chinese Academy of Social Sciences, Sino-Australian-American Collaborative Archaeological Team of the Yiluo River Valley. Pre-Qin period Sites in the East. and Central Luoyang Basin: The Systematic Regional Archaeological Survey Report (1997-2007); Science Press: Beijing, China, 2019. (In Chinese)

92. Field Archaeology Research Center in National Museum of China, Department of Archaeology in Shandong University. The Systematic Archaeological Survey Report of Xue River Basin in Shandong Province; Science Press: Beijing, China, 2017. (In Chinese)

93. Wu, L.; Sun, X.L.; Sun, W.; Zhu, C.; Zhu, T.X.; Lu, S.G.; Zhou, H.; Guo, Q.C.; Guan, H.C.; Xie, W.; et al. Evolution of Neolithic site distribution (9.0-4.0 ka BP) in Anhui, East China. J. Geogr. Sci. 2020, 30, 1451-1466. [CrossRef]

94. Chen, D.D.; Peng, S.Z.; Zhang, W.; Han, J.Q.; Ding, M. The response to Holocene climatic events of Shandong and their impacts on human activity. Prog. Geogr. 2011, 39, 846-852, (In Chinese with English Abstract). 
95. Baxter, M.J.; Beardah, C.C. Some archaeological applications of kernel density estimates. J. Archaeol. Sci. 1997, $24,347-354$. [CrossRef]

96. Wang, L.; Cui, Y.F. The spatiotemporal pattern of cultural evolution response to agricultural development and climate change from Yangshao culture to Bronze age in the Yellow River Basin and surrounding regions, north China. Front. Earth Sci. 2021, 9, 657179. [CrossRef]

97. Dong, G.H.; Wang, L.; Cui, Y.F.; Elston, R.; Chen, F.H. The spatiotemporal pattern of the Majiayao cultural evolution and its relation to climate change and variety of subsistence strategy during late Neolithic period in Gansu and Qinghai Provinces, northwest China. Quat. Int. 2013, 316, 155-161. [CrossRef]

98. Brigand, R.; Weller, O. Neo-Eneolithic settlement pattern and salt exploitation in Romanian Moldavia. J. Archaeol. Sci. Rep. 2018, 17, 68-78. [CrossRef]

99. Cao, W.; Xia, Z.K. Paleo-hydrological signification in mid-Holocene revealed by the analysis of soluble salts of Sihenan profile in Menjin, Henan Province. Acta Sci. Nat. Univ. Pekin. 2008, 44, 933-937, (In Chinese with English Abstract).

100. Li, K.F.; Ma, C.M.; Gao, W.H.; Li, S.Y.; Li, Z.X.; Pan, Y.F. Progress and trend of Holocene environmental archaeology in Henan Province. Prog. Geogr. 2015, 34, 883-897, (In Chinese with English Abstract).

101. He, L.; Xue, C.T.; Ye, S.Y.; Amorosi, A.; Yuan, H.M.; Yang, S.X.; Laws, E.A. New evidence on the spatial-temporal distribution of superlobes in the Yellow River Delta Complex. Quat. Sci. Rev. 2019, 214, 117-138. [CrossRef]

102. Zhao, Y.; Chen, F.H.; Zhou, A.F.; Yu, Z.C.; Zhang, K. Vegetation history, climate change and human activities over the last 6200 years on the Liupan Mountains in the southwestern Loess Plateau in central China. Palaeogeogr. Palaeoclimatol. Palaeoecol. 2010, 293, 197-205. [CrossRef]

103. Xu, Q.H.; Chen, F.H.; Zhang, S.R.; Cao, X.Y.; Li, J.Y.; Li, Y.C.; Li, M.Y.; Chen, J.H.; Liu, J.B.; Wang, Z.L. Vegetation succession and East Asian Summer Monsoon changes since the last deglaciation inferred from high-resolution pollen record in Gonghai Lake, Shanxi Province, China. Holocene 2017, 27, 835-846. [CrossRef]

104. Sun, A.Z.; Guo, Z.T.; Wu, H.B.; Li, Q.; Yu, Y.Y.; Luo, Y.L.; Jiang, W.Y.; Li, X.Q. Reconstruction of the vegetation distribution of different topographic units of the Chinese Loess Plateau during the Holocene. Quat. Sci. Rev. 2017, 173, 236-247. [CrossRef]

105. Li, X.Q.; Shang, X.; Dodson, J.; Zhou, X.Y. Holocene agriculture in the Guanzhong Basin in NW China indicated by pollen and charcoal evidence. Holocene 2009, 19, 1213-1220. [CrossRef]

106. Hosner, D.; Wagner, M.; Tarasov, P.; Chen, X.C.; Leipe, C. Spatiotemporal distribution patterns of archaeological sites in China during the Neolithic and Bronze Age: An overview. Holocene 2016, 26, 1576-1593. [CrossRef]

107. Shi, C.X.; Dian, Z.; You, L.Y. Changes in sediment yield of the Yellow River basin of China during the Holocene. Geomorphology 2002, 46, 267-283. [CrossRef]

108. Xu, J.X. A study of depositional rate in the North China Plain during the past 40000 years, based on ${ }^{14} \mathrm{C}$ dating data from a large wealth of samples. Quat. Sci. 2007, 27, 437-443, (In Chinese with English Abstract). 